Endocrinol. Japon. 1988, 35 (1), 131-134

\title{
Effect of Phosphatidyl Inositol on Progesterone Receptors in Rat Uterine Cytosol
}

\author{
NaOki MITSUHASHI, Masahiko MIZUNO, \\ *AKIKo MIYAGAWA AND *Junzo KATO \\ Department of Obstetrics and Gynecology \\ Faculty of Medicine, University of Tokyo \\ 7-3-1 Hongo, Bunkyo, Tokyo, Japan \\ * Department of Obstetrics and Gynecology \\ Yamanashi Medical University \\ 1110 Shimokato, Nakakoma-gun, Yamanashi, Japan
}

\begin{abstract}
It was reported that unsaturated long chain fatty acids, such as arachidonic acid, oleic acid and docosahexaenoic acid inhibit the binding between progesterone and estrogen receptors and steroid hormones. Most of the long chain fatty acids are contained in phospholipids within the cells. The effect of phospholipids on the binding between R5020 and progesterone receptors was studied. Phosphatidyl ethanolamine and sphingomyelin had no effect on binding, but phosphatidyl inositol and phosphatidyl serine inhibited the binding 53\% and $34 \%$ respectively. The effect of phosphatidyl inositol on the binding between R5020 and progesterone receptors was dose dependent. Scatchard analysis revealed that the addition of phospholipid markedly decreased the number of binding sites from $1398 \mathrm{fmol} / \mathrm{mgp}$ to $258 \mathrm{fmol} / \mathrm{mgp}$, but the dissociation constant was little affected.
\end{abstract}

The binding of estradiol receptors of rat uterine cytosol was inhibited by unsaturated long chain fatty acids (Clec-Hofmann et al., 1983). The binding between R5020 and progesterone receptors was also inhibited by unsaturated long chain fatty acids in the same manner (Mitsuhashi et al., 1986). On the other hand, saturated fatty acids or prostaglandins had no effect on the steroid hormone receptors. Most of the unsaturated fatty acids are contained in phospholipid within the cells (Ansell et al., 1973). In this paper, the effect of phospholipids on

Received August 11, 1987 the progesterone receptors of rat uterine cytosol was investigated.

\section{Materials and Methods}

\section{Materials}

Female rats of Wistar strain (Animal Breeding Laboratories, Ohmiya, Saitama) were used. At 27 days of age they were injected with $10 \mu \mathrm{g}$ diethylstilbestrol (DES) subcutaneously, and 24 hours later decapitated. The uterus was dissected and washed in ice-cold $10 \%$ glycerol Tris buffer ( $\mathrm{pH}$ 7.4) containing $20 \mathrm{mM}$ sodiummolybdate and $1 \mathrm{mM}$ dithiothreitol $(10 \%$ glycerol-Tris buffer). The uterus was blotted on 
filter paper and weighed, cut into small pieces and homogenized in 3 volumes (weight/vol.) of $10 \%$ glycerol-Tris buffer with a Teflon pestle in a homogenizer (five strokes, $600-1000 \mathrm{rpm}, 3$ $\min$.) at $4^{\top} \mathrm{C}$. The homogenates were then centrifuged at $105,000 \mathrm{~g}$ for $1 \mathrm{~h}$ in a Beckman L5-50 ultracentrifuge.

\section{Sephadex LH-20 columns}

The cytosols $(200 \mu \mathrm{l})$ were incubated with phospholipids for $15 \mathrm{~min}$. and further incubated with ${ }^{3} \mathrm{H}-\mathrm{R} 5020$ at $0-4^{\circ} \mathrm{C}$ for $4 \mathrm{~h}$. After incubation $150 \mu \mathrm{l}$ aliquots were applied to Sephadex LH-20 columns. The columns were washed with $50 \mu \mathrm{l}$ of TEGD buffer $(10 \mathrm{mM}$ Tris, $1.5 \mathrm{mM}$ sodium EDTA, $10 \%$ glycerol, $1 \mathrm{mM}$ dithiothreitol) and then eluted with TEGD buffer. The eluate $(400 \mu \mathrm{l})$ was counted for radioactivity.

\section{Chemicals}

Redistilled and purified solvents and reagent grade chemicals were used in all experiments. Tritiated R5020 (S.A. $86 \mathrm{Ci} / \mathrm{mmol}$ ) and radioinert R5020 were obtained from New England Nuclear Corp., Boston Mass.. Phospholipids were obtained from Funakoshi Co., Tokyo. Diethylstilbestrol was obtained from Teikoku Zoki Co., Tokyo. Glycerol (Merck Japan), Dextran T70 (Pharmacia Fine Chemicals) and Norit A (American Norit Co.) were used. Dithiothreitol was purchased from SIGMA Chemicals, Inc., St. Louis, Mo.

\section{Results}

Twenty $\mu \mathrm{g}$ of phosphatidyl inositol (PI), phosphatidyl serine (PS), phosphatidyl ethanolamine (PE) and sphingomyelin (S) dissolved in $5 \mu \mathrm{l}$ of chloroform were added to the incubation mixture. Tritiated R-5020 was added $1.05 \mathrm{nM}$. As shown in Fig. 1, $P E$ and $S$ had no effect on the binding between R5020 and progesterone receptors, but PS and PI had an inhibitory effect on the binding. The addition of PI resulted in $47 \%$ binding and that of PS in $66 \%$ compared of the control.

This inhibitory effect of PI was studied. As shown in Fig. 2, between $1 \mu \mathrm{g} / 215 \mu \mathrm{l}$ and $40 \mu \mathrm{g} / 215 \mu \mathrm{l}$, PI inhibited the binding

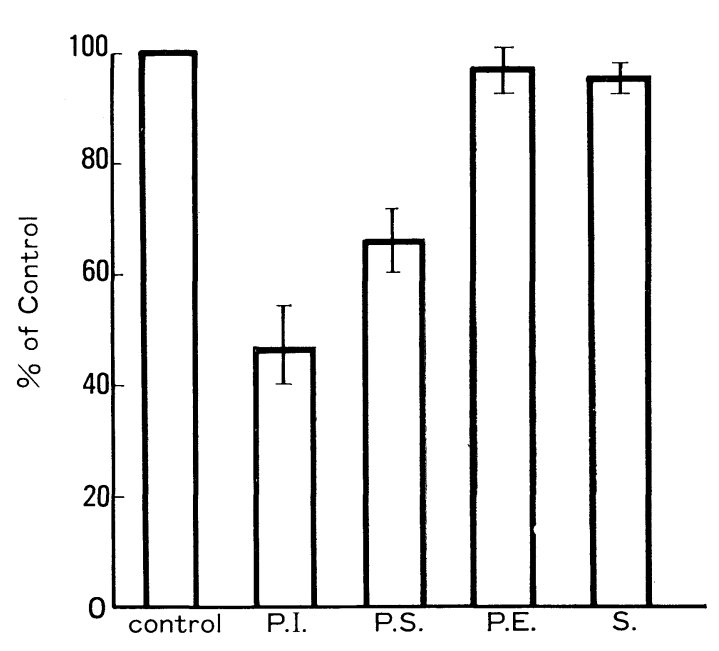

P.I. : Phosphatidyl Inositol, P.S. : Phosphatidyl serine P.E. : Phosphatidyl Ethanolamine, S. : Sphingomyelin $(N=5$, meant SD)

Fig. 1. Effect of phospholipids on the binding between R5020 and progesterone receptor. $20 \mu \mathrm{g} / 215 \mu \mathrm{l}$ phospholipids were added. 1.05 $\mathrm{nM}$ tritiated R-5020 was added.

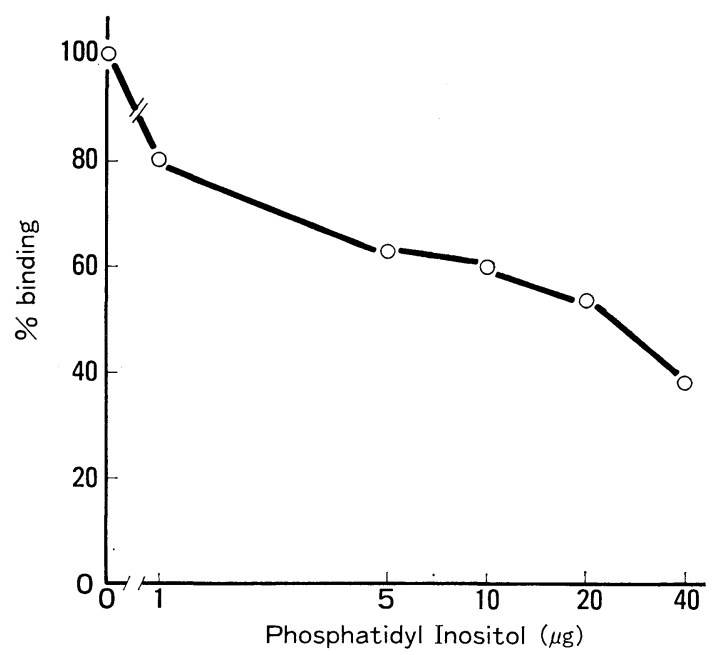

Fig. 2. Effect of phosphatidyl inositol on the binding between R5020 and progesterone receptor. $1 \mu \mathrm{g} / 215 \mu \mathrm{l}$ to $40 \mu \mathrm{g} / 215 \mu \mathrm{l}$ phosphatidyl inositol was added. 


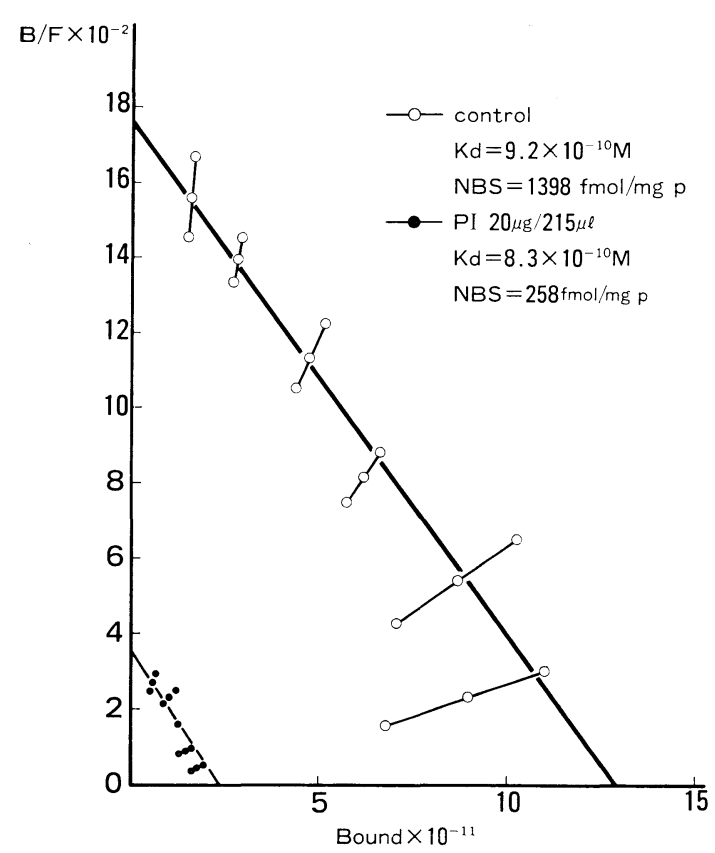

Fig. 3. Scatchard analysis of the effect of phosphatidyl inositol on the binding of R5020 and progesterone receptor.

dose dependently. Scatchard analysis revealed that the dissociation constants changed from $9.2 \times 10^{-10} \mathrm{M}$ to $8.3 \times 10^{-10} \mathrm{M}$ following the addition of $20 \mu \mathrm{g}$ of PI. In contrast to this small change in the dissociation constants, the number of binding sites changed from $1398 \mathrm{fmol} / \mathrm{mgp}$ to 258 $\mathrm{fmol} / \mathrm{mgp}$.

\section{Discussion}

In this series of experiments, phospholipids were dissolved in chloroform. Chloroform $(5 \mu 1)$ was added to the incubation mixture and the final volume was $215 \mu \mathrm{l}$. Therefore the chloroform content was only $2.3 \%$. In the preliminary study, the number of binding sites of the cytosol $(25 \mu \mathrm{gp} /$ $215 \mu \mathrm{l})$ with or without $2.3 \%$ chloroform were $478.5 \mathrm{fmol} / \mathrm{mgp}$ and $486.5 \mathrm{fmol} / \mathrm{mgp}$ respectively, so chloroform had little effect on the binding between R5020 and progesterone receptors.

Unsaturated fatty acids such as arachidonic acid had a strong inhibitory effect on the progesterone and estrogen receptors (Clec-Hofmann et al., 1983) (Mitsuhashi et al., 1986). The phospholipid contained two fatty acids as side chains. The side chain in the $\mathrm{C} 2$ position can be released by the action of phospholipase A (van den Bosch et al., 1983), so there is some doubt that this inhibitory effect of PI and PS is carried by the fatty acids released. But the incubation conditions were $0-4^{\circ} \mathrm{C}$ for $4 \mathrm{~h}$, so there was little possibility that the side chains of phospholipid were removed.

The mechanisms by which phospholipids decrease the number of binding sites but do not affect the dissociation constant have not been clarified. However, unsaturated fatty acids inhibit estrogen and progesterone receptors in the same manner (unpublished data).

The physiological significance of this inhibitory effect has not been clarified. Steroid hormones are believed to get into the target cells freely and bind to the receptors (Gorski et al., 1986) (Jensen et al., 1962). Phospholipids and fatty acids may have some modulatory effect on the binding of steroid hormones and receptors.

\section{References}

Ansell, G. B., J. N. Hawthorne and R. M. C. Dawson ed. (1973). Form and Function of Phospholipids. B. B. A. Library Vol. 3.

van den Bosch, H. (1983). Phospholipase: Link between Membrane Phospholipids and Arachidonate Metabolites. Leukotrienes and Prostacyclin, ed. by F. Berti, G. Folco and G. P. Velo, NATO ASI Series 54, 1-14.

Clec-Hofmann, F., G. Vallette, C. S. Millet, N. Christef, C. Benassayag and E. A. Nunez (1983). Inhibition of the uterine binding estrogens by unsaturated fatty acids in the 
immature rat. C. R. Acad. Sci. Paris. 296, Jensen, E. V. and H. I. Jacobson (1962). Basic 53-58. Guides to the Mechanism of Estrogen Action. Gorski, J., D. Toft, G. Shyamala, D. Smith and A. Notides (1968). Hormone Receptors: Studies on the Interaction of Estrogen with the Uterus. Recent Prog. Horm. Res. 24, 4580 . Recent Prog. Horm. Res. 18, 387-414.

Mitsuhashi, N., A. Takano and J. Kato (1986). Inhibition of the Binding of R-5020 and Rat Uterine Progesterone Receptors by Long Chain Fatty Acids. Endocrinol. Japon. 33, 251-256. 